\title{
Russian energy projects in South Africa
}

\author{
J. An ${ }^{1}$, A. Mikhaylov ${ }^{*}$ \\ 1 College of Business, Hankuk University of Foreign Studies, Seoul, Korea; ORCiD: https://orcid.org/0000-0001- \\ 5410-7506 \\ 2 Financial University under the Government of the Russian Federation, Moscow, Russia; https://orcid.org/0000- \\ 0003-2478-0307
}

\begin{abstract}
From early 2019, South Africa and Russia have planned to increase their energy trade. Russia can become one of the world's five largest energy exporters. This study examines of the cost of a kilowatt of electricity generated by coal power projects in South Africa and compares nuclear electricity with other types of green energy. This method must help to improve the management decisionmaking process in South Africa for energy exporta. Reasons for this persistence include the marketing strategies of Russian companies for seeking new markets in industrialised and postindustrial countries where, due to intensive competition, sales of Russian high-tech products are often unsuccessful. Renewable energy gives a chance to potentially reduce poverty in South Africa. The study concludes that imported crude oil is more suited to the needs of the refining industry of South Africa. The consumption for this type of energy in areas not concerning industry is insignificant and its increase is unlikely to be observed in the future.
\end{abstract}

Keywords: Energy sources, South African energy policy, resource saving, economic development, energy cooperation.

\section{Highlights}

- Nuclear energy is popular energy source in South Africa now.

- Provision of sustainable energy services helps to find the sources for economic growth.

- Renewable energy technologies have opportunity for reduce nuclear production in South Africa.

- Bio-energy can become the main source of energy in South Africa.

Journal of Energy in Southern Africa 31(3): 58-64

DOI: http://dx.doi.org/10.17159/2413-3051/2020/v31i3a7809

This work is licensed under a Creative Commons Attribution-ShareAlike 4.0 International Licence

Published by the University of Cape Town ISSN: 2413-3051

https://journals. assaf.org.za/jesa

Sponsored by the Department of Science and Innovation

\footnotetext{
* Corresponding author: Leningradsky av., 49, Moscow, Russia;

tel: +79 01908 9817; email: alexeyfa@ya.com
} 


\section{Introduction}

Africa already provides $21 \%$ of the world labor resources, and by 2025 this will increase to $30 \%$, and after 2050 the world labor market will increase by $65 \%$ at the expense of the African population. The continent has a huge potential for intensive development, and Russian business has a unique chance to promote Russian technology there.

According to the forecast published in 2015 , the population of even large African countries will experience a rapid growth in the second half of this century (An and Dorofeev, 2019). In 2015 the population of Africa was 1.2 billion, and this is forecast to increase by 2035 to 1.9 billion. The median age in Africa is 15-19 years. Most subSaharan African countries will double in population over the next 20 years.

The energy partnership between Russia and South Africa is beneficial to both countries: additional boost for Russia and business to solve the problem of energy shortages in Africa. Energy cooperation, development and diversification of imports is a key area of foreign economic and foreign policy activities of the Russian government, relevant ministries and private companies. In this regard, the Russian side should look for ways to strengthen such cooperation. Obviously, it will be mutually beneficial and long-term cooperation, taking into account geographic and geological factors for new energy projects in South Africa.

South Africa is one of the most promising markets for Russian investments in the medium and long terms. So Russian energy projects in South Africa can be very attractive. South Africa need new technologies and a rapidly growing population (at a rate of about $2.5 \%$ per year) will ensure an increase in demand for the next decades.

\section{Literature review}

High rates of industrialisation in Africa and a rapidly growing population will cause a sharp increase in the demand for electricity there in the next few decades, including in South Africa, which is Africa's most developed country in terms of its energy sector. Since 1990, South Africa has successfully implemented a country-wide electrification programme (Meynkhard, 2019; Denisova et al., 2019).

The tariffs of Eskom, the South African power monopoly, grew by $300.7 \%$ since the beginning of the energy crisis (Milbrabdt et al., 2014; Morgan and Yang, 2001).

Despite government's attempts to build up and diversify energy capacities, the last ten years have seen little change (Nyangarika et al., 2019a; Nyangarika et al., 2019b; Ang, 2007; Ang, 2009).

By 2021, without the introduction of new energy capacities, the country will again face energy deficiency problem (Gardner et al., 1993; An et al., 2020). The situation is aggravated by the need for a substantial reduction in the coal-based power plants that produce the vast majority of electricity by 2030, in accordance with the Paris Climate Agreement signed by South Africa. Otherwise the country faces significant fines (USD5/ $\mathrm{tCO}^{2}$ ). At present, South Africa is one of the twenty highest emitters of $\mathrm{CO}^{2}$ into the atmosphere (Mikhaylov, 2018a; 2018b; Meynkhard, 2019; Apergis, Payne, 2009; Apergis, Payne, 2010).

In October 2010, the Ministry of Energy of South Africa published the Integrated Resource Plan (IRP) 2010-2030. The IRP was revised several times, most recently in 2016. According to it, by 2050 it is planned to build new power plants of different types that will more than double total power generation in South Africa by more than two times, up to $125 \mathrm{GW}$ (20.4 GW from nuclear power plants; 17.6 GW from solar power plants; $37.4 \mathrm{GW}$ from wind power plants; 35.9 GW from gas turbine power plants; and $15.2 \mathrm{GW}$ from other sources) (Moiseev, 2017c; Moiseev, Akhmadeev, 2017; Mikhaylov, 2019a).

As for development of nuclear energy, it is planned to build general power units with a capacity of $20.4 \mathrm{GW}$ by 2050 . The first stage envisages the construction of two nuclear power plants, most likely at Thyspunt in the east part of the country (Ivanyuk, Soloviev, 2019).

The opinion expressed by Russian diplomats that, if successful, the Rosatom project could attract Russian business to South African and African markets (Zubakin et al., 2015). The problems of European countries' dependence on natural gas, liberalization of the European gas market and energy cooperation with Russia and the South Africa region was considered as domestic (Tazvinga and Hove, 2010; Tazvinga et al., 2017; Wang and Nehrir, 2008; Wang et al., 2020).

\section{Data and methods}

One of the most effective solutions to the problems of South African energy shortages could be the construction of nuclear power plants. South Africa is already the only state in Africa that has a functioning nuclear power plant, at Koeberg. In the long term, 
nuclear energy is capable of not only providing surplus electricity in South Africa, but also contributing to a "soft" transition from coal-fired power plants to environmentally friendly green technology, but nuclear energy index stay into the flat. Nuclear energy index shows that level of world nuclear energy production goes to the south in the period from 2014-2016 and keeps in stable position in the period from 2017-2019 (Figure 1).

Solar panels and solar power plants are not able to provide constant stable new electricity generation (24 hours /day), in contrast to nuclear power plants. Distribution of additional incomes in favour of the population will have an important social effect (Moiseev, 2017a; Moiseev, 2017b; Moiseev, Sorokin, 2018).

The nuclear plants will be built by the company that wins the tender. There are three main companies that have the requisite technology: Japanese Westinghouse, Russian Rosatom, and French Areva. The latter two are the main competitors for the South African plants (especially after the bankruptcy of Westinghouse in 2017). Rosatom is at present the only manufacturer that offers a full cycle of nuclear energy production (Mikhaylov et al., 2019; Ang, 2008; Meynkhard, 2020; Lopatin, 2019b).

Rosatom has confirmed its interest in providing appropriate support. At the same time, the Ministry of Energy of South Africa has proposed postponing the nuclear project for 14 years, because at present there is neither the necessary demand nor the financial resources for the construction of nuclear plants. (Radosteva et al., 2018, Elizarov et al., 2017).

On the one hand, and the scientific and industrial potential of the Russian Federation, on the other hand, have a base value of joint investment projects. The project customer was the industrial holding, Dawn Group. The parties plan to create a network of roofing solar electric stations for energy supply of a complex of warehouse and logistics facilities in South Africa with a total capacity of 5 MW. An agreement was been signed in the spring of 2013. Its main condition is the provision of logistics holding's infrastructure with electricity at a price lower than the network (Sunchalin et al, 2019; Ivanyuk, 2018).

Following the announcement of the intention of the South African authorities to build a new nuclear power plant, Rosatom has been actively involved in the competition for the project. South Africa will become the continent's 'nuclear hub'. Further, many Russian suppliers will come to the African market. GDP growth for 2016-2017 is of particular interest: in developed countries it amounted to only $0.5 \%$, South Africa experienced its decline, Russia's GDP tended to grow by $1.6 \%$, and Europe only $0.3 \%$. It is worth noting that the key principle of the formation of a global energy security system is the rational use of traditional energy resources in the context of their limited nature and the gradual increase in the share of alternative energy sources in the energy balance of countries (Ajoku, 2012; Atalay et al., 2011; Asongu, 2018; Asongu et al., 2017a; Asongu et al., 2017b).

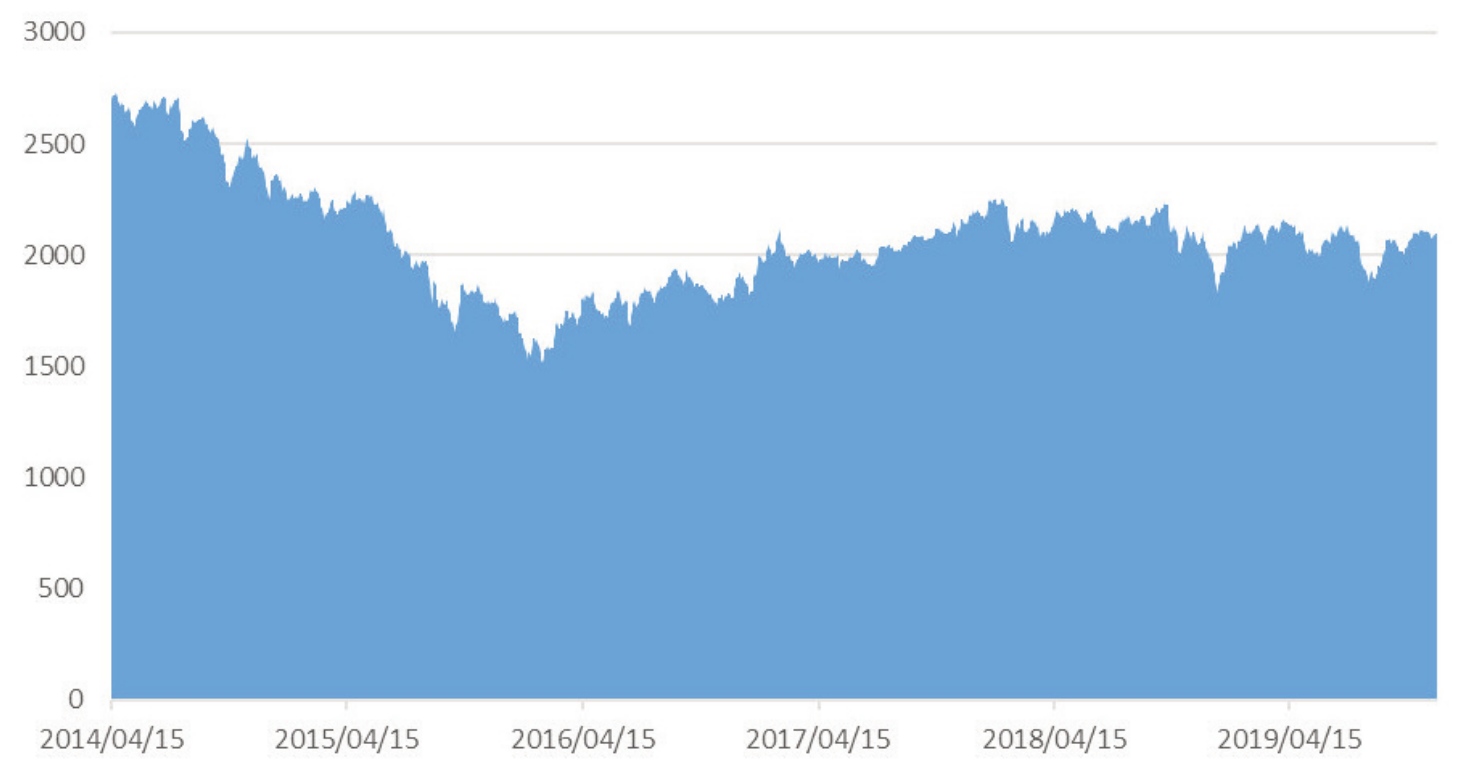

Figure 1: Southern New England Telecommunications nuclear energy index. 
The demographic situation in the region is that growth in the number of population, a large proportion of the young people, as well as government measures, aimed at lowering the energy intensity of the economy as a whole. Accordingly, 38.2\% of bitumen goes to final consumption and is used mainly in the industrial sector (98.3\%) - metallurgical industry - and in housing and commercial sector (1.7\%) - for residential heating. (Vigolo et al., 2018; Wellinger et al., 2013; Zakeri and Syri, 2015; Meynkhard, 2020b; Meynkhard, 2019b; Trubnikov et al., 2020).

In 2020, growth is expected to increase to $2.8 \%$ under the influence of easing geopolitical tensions and rising oil prices. In geopolitics, South Africa is traditionally has Western establishment, it is reacting painfully to the increasing influence of other countries (whether China or Russia) in South Africa. It is possible to use the pension funds of civil servants, but this will generate fierce political opposition. The main competitor of Rosatom in the fight for the tender is the French company Areva. Its main advantage is the existing two-reactor nuclear power plant in Koeberg (Lisin, 2020a; Lisin, 2020b; Lisin, 2020c; Lopatin, 2020; Uandykova et al., 2020).

\section{Results}

In geopolitics, South Africa is traditionally has Western establishment, it is reacting painfully to the increasing influence of other countries (whether China or Russia) in South Africa.

This paper covers the time period from 2014 to 2019, due primarily to the fact that officially diplomatic relations between the Russian Federation and South Africa were established a long time ago, and throughout over the next few years, major contracts were signed, following by signing the relevant contracts that served as the institutional core for development of energy cooperation between two states. But The period from 2014 to 2019 is the beginning of fuel and energy cooperation by increasing energy exports and the development of some joint projects in this area.

The last year is characterized by global challenges for the global energy system, which cannot but affect the economy of the Russian Federation, for which the fuel and energy sector is strategically important. Recent trends, which are manifested as a slowdown in global economic growth and an excess of the aggregate supply of hydrocar- bons over their demand, lead to a drop in energy prices and increased cross-country tensions, both for producing countries and recipient countries. It leads to toughening cross-country competition and requires the search for new innovative solutions in the field of energy security and stability.

One of the main tasks of Russian Federation is to improve the production structure of fuel and energy complex, which includes the creation of new energy industrial complexes, which would stimulate the development of regions such as Siberia, the Far East and the Arctic along with diversification of the geographical structure of exports with a bias in the Asia-Pacific region.

The development of energy infrastructure in these regions is also one of priorities of state energy policy. Thus, the main directions of development of the energy sector will be to export diversification, increasing the share of African exporting countries, improving the creation of new energy infrastructure projects in Siberia, at the Far East and the Arctic, as well as attracting investment in the energy sector. Favorable conditions are created in the near future for the development of energy cooperation with South Africa, since both sides, as it will be demonstrated below, have complementary goals and interests in energy sphere.

The authors of this paper achieved their goals through consistent solving of the following tasks:

1. to identify and analyse the methodological basis of energy cooperation of South Africa and the Russian Federation, including the concepts, theories and strategies of the parties involved;

2. to study the factors contributing to the development of energy cooperation of the Republic of South Korea and the Russian Federation;

3. to find out what is the institutional base of energy cooperation of the Republic of South Korea and the Russian Federation and give it an analysis;

4. to consider the main joint projects of South Africa and the Russian Federation in the field of energy cooperation, including active, suspended and those in development;

5. to identify and analyse conditions and problems that impede strengthening and expanding energy cooperation between South Africa and the Russian Federation; and

6. to analyse the current political situation in South Africa and the Russian Federation 
and identify how it contributes to or hinders the deepening of energy cooperation.

\section{Conclusion}

Another area of cooperation could be bioenergy. Russian companies was reached agreement with the government of the Mpumalanga province. As a result, further successful expansion of Russian energy technologies into Africa is possible. But renewable energy technologies have opportunity for reduce nuclear production in South Africa.

Almost the entire economy of the country and the welfare of the people depend on well-established and stable energy supplies. Thus, from the above analysis, the study concludes that imported crude oil is more suited to the needs of the refining industry. The consumption for this type of energy in areas not concerning industry is insignificant and its increase is unlikely to be observed in the future. Provision of sustainable energy services help to find the sources for economic growth.

Besides, natural gas, coal and nuclear make up the most demand for energy. The share of oil and other liquid energy resources will continue to decrease and according to estimates for 2014 to 2018, their share in the total energy consumption will decrease from 40 to $34 \%$.

Consequently, energy cooperation, its development and diversification of imports is a key area of foreign economic and foreign policy activities of the government, relevant ministries and private companies. In this regard, the Russian side should look for ways to strengthen such cooperation. Obviously, it will be mutually beneficial and long-term cooperation, taking into account geographic and geological factors. Bio energy can become the main source of energy in South Africa.

\section{Author roles}

J. An: Conceptualisation; software; validation; formal analysis.

A. Mikhaylov: Writing - original draft; software.

\section{Acknowledgements}

The first author was supported by Hankuk University of Foreign Studies Research Fund.

\section{References}

Ajoku, K.B., 2012. Modern use of solid biomass in Africa: Prospects for utilization of agro-waste resources in Nigeria. Bio-energy for sustainable development in Africa, pp. 131-146.

An, J., Dorofeev, M., 2019. Short-term FX forecasting: decision making on the base of expert polls. Investment Management and Financial Innovations 16(4), 72-85.

An, J., Dorofeev, M., Zhu, S., 2020. Development of Energy Cooperation Between Russia and China. International Journal of Energy Economics and Policy 10 (1), 134-139.

Ang, J.B., 2007. Are saving and investment cointegrated? The case of Malaysia (1965-2003). Applied Economics 39, 2167-2174.

Ang, J.B., 2008. Economic development, pollutant emissions and energy consumption in Malaysia. Journal of Policy Modeling 30, 271-278.

Ang, J.B., 2009. CO2 emissions, research and technology transfer in China. Ecological Economics 68, 2658-2665.

Apergis, N., Payne, J.E., 2009. CO2 emissions, energy usage, and output in Central America. Energy Policy 37, 3282-3286.

Apergis, N., Payne, J.E., 2010. The emissions, energy consumption and growth nexus: evidence from the commonwealth of independent states. Energy Policy 38, 650-655.

Apergis, N., Payne, J.E., Menyah, K., Wolde-Rufael, Y., 2010. On the causal dynamics between emissions, nuclear energy, renewable energy, and economic growth. Ecological Economics 69, 2255-2260.

Asongu, S.A., 2018. Comparative sustainable development in Sub-Saharan Africa. Sustainable Development, 1-14.

Asongu, S.A., Le, S., Biekpe, N., 2017a. Environmental degradation, ICT and inclusive development in Sub-Saharan Africa. Energy Policy, 111, 353-361.

Asongu, S.A., Le, S., Biekpe, N., 2017b. Enhancing ICT for environmental sustainability in sub-Saharan Africa. Technological Forecasting and Social Change, 1-8.

Atalay, E., Hortacsu, A., Roberts, J., Syverson, C., 2011. Network structure of production. Proceedings of the National Academy of Sciences, 108(13), 5199-5202.

Denisova, V., Mikhaylov, ., Lopatin, E., 2019). Blockchain infrastructure and growth of global power consumption. International Journal of Energy Economics and Policy 9(4), 22-29. 
Elizarov, M., Ivanyuk, V., Soloviev, V., Tsvirkun, A., 2017. Identification of high-frequency traders using fuzzy logic methods. Proceedings of 2017 10th International Conference Management of Large-Scale System Development, MLSD 2017. https://doi: 10.1109/MLSD.2017.8109615i

Ivanyuk, V., 2018. Econometric Forecasting Models Based on Forecast Combination Methods. Proceedings of 2018 11th International Conference Management of Large-Scale System Development, MLSD 2018. https://doi: 10.1109/MLSD.2018.8551825

Ivanyuk, V., Soloviev, V., 2019. Efficiency of neural networks in forecasting problems. Proceedings of 2019 12th International Conference Management of Large-Scale System Development; MLSD 2019. https://doi: 10.1109/MLSD.2019.8911046

Jaramillo, P., Matthews, H.S., 2005), Landfill-gas-to-energy projects: Analysis of net private and social benefits. Environmental Science and Technology, 39, 7365-7373.

Lisin, A, 2020c. Valuation of the activities of foreign banks in the Russian banking sector. Orbis, 15(45), 53-63. http://www.revistaorbis.org.ve/pdf/45/art5.pdf

Lisin, A., 2020a. Biofuel Energy in the Post-oil Era. International Journal of Energy Economics and Policy, 10(2), 194-199. https://doi.org/10.32479/ijeep.8769

Lisin, A., 2020b. Prospects and Challenges of Energy Cooperation between Russia and South Korea. International Journal of Energy Economics and Policy, Vol. 10 (3). https://doi.org/10.32479/ijeep.9070

Lopatin, E., 2019a. Methodological Approaches to Research Resource Saving Industrial Enterprises. International Journal of Energy Economics and Policy 9(4), 2019, 181-187.

Lopatin, E., 2019b. Assessment of Russian banking system performance and sustainability. Banks and Bank Systems, 14(3), 202-211. doi:10.21511/bbs.14(3).2019.17

Lopatin, E., 2020. Cost of Heating Pump Systems in Russia. International Journal of Energy Economics and Policy, Vol. 10 (3). DOI: https://doi.org/10.32479/ijeep.9056

Meynkhard, A., 2019. Energy efficient development model for regions of the Russian Federation: Evidence of crypto mining. International Journal of Energy Economics and Policy 9(4), 2019, 16-21.

Meynkhard, A., 2019b. Fair market value of bitcoin: halving effect. Investment Management and Financial Innovations, 16(4), 72-85. https://doi.org/10.21511/imfi.16(4).2019.07

Meynkhard, A., 2020. Priorities of Russian energy policy in Russian-Chinese relations. International Journal of Energy Economics and Policy 10 (1), 65-71. https://doi.org/10.32479/ijeep.8507

Meynkhard, A., 2020b. Long-term prospects for the development energy complex of Russia. International Journal of Energy Economics and Policy, 10(3), . 224-232.

Mikhaylov, A., 2018a. Pricing in oil market and using probit model for analysis of stock market effects. International Journal of Energy Economics and Policy, 2, 69-73.

Mikhaylov, A., 2018b. Volatility spillover effect between stock and exchange rate in oil exporting countries. International Journal of Energy Economics and Policy, 2018, 8(3), 321-326.

Mikhaylov, A., 2019. Oil and gas budget revenues in Russia after crisis in 2015. International Journal of Energy Economics and Policy 9(2), 2019, 375-380.

Mikhaylov, A., Sokolinskaya, N., Lopatin, E., 2019. Asset allocation in equity, fixed-income and cryptocurrency on the base of individual risk sentiment. Investment Management and Financial Innovations, 16(2), 171-181. doi:10.21511/imfi.16(2).2019.15

Mikhaylov, A., Sokolinskaya, N., Nyangarika, A., 2018, Optimal carry trade strategy based on currencies of energy and developed economies. Journal of Reviews on Global Economics 7, 582-592. DOI: https://doi.org/10.6000/1929-7092.2018.07.54

Milbrabdt, A.R., Heimiller, D.M., Perry, A.D., Field, C.B., 2014, Renewable energy potential on marginal lands in the United States. Renewable and Sustainable Energy Review, 29, 473-481.

Moiseev, N., 2017a. Forecasting time series of economic processes by model averaging across data frames of various lengths. Journal of Statistical Computation and Simulation, 87 (17). - P. 3111-3131.

Moiseev, N., 2017b. p-Value adjustment to control type I errors in linear regression models. Journal of Statistical Computation and Simulation, 87 (9). - P. 1701-1711.

Moiseev, N., 2017c. Linear model averaging by minimizing mean-squared forecast error unbiased estimator. Model Assisted Statistics and Applications, 11 (4). - P. 325-338.

Moiseev, N., Akhmadeev, B., 2017. Agent-based simulation of wealth, capital and asset distribution on stock markets. Journal of Interdisciplinary Economics, 29 (2). - P. 176-196.

Moiseev, N., Sorokin, A., 2018. Interval forecast for model averaging methods. Model Assisted Statistics and Applications, 18 (2). - P. 125-138.

Morgan, S.M., Yang, Q., 2001. Use of landfill gas for electricity generation. Practice Periodical of Hazardous, Toxic, and Radio Waste Management, 5(1), 14-24.

Morris, J.W., Barlaz, M.A., 2011. A performance-based system for the long-term management of munici- 
pal waste landfills. Waste Management, 31(4), 649-662.

Nyangarika, A., Mikhaylov, A. \& Richter, U., 2019b. Oil price factors: Forecasting on the base of modified auto-regressive integrated moving average model. International Journal of Energy Economics and Policy, 9(1), 149-160. https://doi.org/10.32479/ijeep.6812

Nyangarika, A., Mikhaylov, A. \& Tang, B.-J., 2018. Correlation of oil prices and gross domestic product in oil producing countries. International Journal of Energy Economics and Policy, 8(5), 42-48.

Nyangarika, A., Mikhaylov, A., \& Richter, U., 2019a. Influence oil price towards economic indicators in Russia. International Journal of Energy Economics and Policy, 9(1), 123-130. https://doi.org/10.32479/ijeep.6807

Radosteva, M., Soloviev, V., Ivanyuk, V., Tsvirkun, A., 2018. Use of neural network models in market risk management. Advances in Systems Science and Applications, 18 (2), pp. 53-58. https://doi: 10.25728/assa.2018.18.2.582

Sunchalin, A.M., Kochkarov, R.A., Levchenko, K.G., Kochkarov, A.A., Ivanyuk, V.A., 2019. Methods of risk management in portfolio theory. Espacios, 40(16).

Tazvinga, H. and Hove, T. 2010. Technical model for optimising PV/diesel/battery hybrid power systems, 3rd CSIR Biennial Conference, CSIR International Convention Centre: Pretoria, 1 August - 01 September 2010. Available at: http://researchspace.csir.co.za/dspace/handle/10204/4229.

Tazvinga, H., Thopil, M., Numbi, P.B. and Adefarati, T. 2017. Distributed renewable energy technologies. In Handbook of Distributed Generation: 3-67). Springer, Cham.

Trubnikov, V., Meynkhard, A., Shvandar, K., Litvishko, O., Titov, V., 2020. Medication market performance analysis with help of Analytic Hierarchy Processing. Entrepreneurship and sustainability Issues, 8(1), 899-916. http://doi.org/10.9770/jesi.2020.8.1(60).

Uandykova, M., Lisin, A., Stepanova, D., Baitenova, L., Mutaliyeva, L., Yuksel, S., Dincer, H., 2020. The social and legislative principles of counteracting ransomware crime. Entrepreneurship and Sustainability Issues 8(2), 777-798. http://doi.org/10.9770/jesi.2020.8.2(47).

Vigolo, V., Sallaku, R. and Testa, F. 2018. Drivers and barriers to clean cooking: A systematic literature review from a consumer behaviour perspective. Sustainability, 10(11): 4322.

Wang, C. and Nehrir, M.H. 2008. Power management of a stand-alone wind/photovoltaic/fuel cell energy system. IEEE Transactions on Energy Conversion, 23(3): 957-967.

Wang, Y., Diaz, D.F.R., Chen, K.S., Wang, Z. and Adroher, X.C. 2020. Materials, technological status, and fundamentals of PEM fuel cells-a review. Materials Today, 32: 178-203.

Wellinger, A., Murphy, J.D. and Baxter, D., 2013. The biogas handbook: science, production and applications. Elsevier.

Zakeri, B. and Syri, S. 2015. Electrical energy storage systems: A comparative life cycle cost analysis. Renewable and Sustainable Energy Reviews, 42: 569-596.

Zubakin, V.A., Kosorukov, O.A., Moiseev, N.A., 2015. Improvement of regression forecasting models. Modern Applied Science, 9 (6), 344-353. 